\title{
From Food Crisis to Agrarian Crisis? Food Security Strategy and Rural Livelihoods in Vietnam
}

\author{
Timothy Gorman
}

In 2007 and 2008, the world was gripped by a dramatic food crisis, as a confluence of factors-including the rising price of oil and oil-derived inputs like fertilizer and the dwindling of reserve food stocks across the Global South - conspired to drive the prices of staples like wheat and rice to record heights (Brown 2012). The crisis revealed new sources of instability lurking within the global food system, as grain traders took advantage of financialized commodity markets to reap speculative profits, driving up staple prices in the process, and as a growing reliance on food imports left countries around the world fully exposed to volatility in world price levels (Clapp and Cohen 2009). Across the Global South, high prices and scarce supplies touched off food riots and social unrest, culminating most dramatically in the uprisings that rocked the Arab world (Naylor 2014, p. 15; Barrett 2013; Patel and McMichael 2014).

Even Vietnam, a country that has made massive strides in strengthening its food security in recent decades, was not immune to the contagion. ${ }^{1}$

\footnotetext{
T. Gorman $(\bowtie)$

Department of Sociology, Montclair State University, Montclair, NJ, USA e-mail: gormant@montclair.edu 
Over the course of just a few days in April of 2008, the price of rice in Ho Chi Minh City doubled, reaching more than 20,000 Vietnamese Dong (VND) (or USD 1.3) per kilo, driven in part by the hoarding of supplies and the diversion of the rice harvest to export markets, where prevailing prices were even higher (Ngan 2010, p. 220). A contemporary account in the Saigon Economic Times (Thời báo Kinh tế Sài Gòn) described the scene: "In the past 20 years, we have not seen the sight of people lining up, shoving, and even fighting one another over a bag of rice. This may be the first time since 1989," claims the author, Hồng Văn, referring to the last years of socialist-era economic planning, "when people have had to line up to buy rice" (Văn 2008). Economist Peter Timmer, who has written extensively on the political economy of rice in Asia, expressed disbelief over the extent of the "panic" in Vietnam in a 2011 interview: "In Ho Chi Minh City, for heaven's sake, the center of the second-largest rice exporting surplus in the world, supermarkets and rice markets got cleaned out in two days" (Charles 2011).

The response of urban consumers to the rapid rise in rice prices and the perception of impending shortages illustrates the high degree of anxiety that continues to persist around rice and rice supplies in Vietnam, despite two decades of relative abundance that have followed the implementation of market reforms in the late 1980s. These anxieties were manifested not just in the queues that formed outside supermarkets in Ho Chi Minh City, but in the Vietnamese government's response to the crisis. In the face of rapidly rising rice prices, the government first moved to block rice exports; taking advantage of the structural legacies of the socialist era, in March 2008, the Prime Minister ordered the state-owned companies that dominate Vietnam's rice exports to cut outbound shipments and refrain from signing new contracts with foreign buyers (Alavi et al. 2012; Ngan 2010). Simultaneously, the government sought to crack down on the smaller private export sector by reducing quotas, raising minimum export prices above market levels, and implementing an export tax (Ngan 2010). This immediate attempt to stabilize the price and supply of rice was supplemented in 2009 by the promulgation of Resolution No. 63/NQ-CP, which sets out a long-term strategy aimed at ensuring Vietnam's food security and reducing the country's exposure to the volatility of global rice markets (see Zhang, this volume). 
This chapter is a critical examination of the post-crisis food security strategy outlined in Resolution 63. The first half of the chapter consists of a close analysis of the text of the resolution itself, and focuses specifically on how "food security" is defined in the document and how this conceptualization reflects the cultural, historical, and political context in which it was formed. The second half of the chapter then draws from the perspectives of critical agrarian studies, and especially the concepts of "agrarian transition" (Byres 1977) and "agrarian crisis" (De Janvry 1981), to examine how the food security strategies encapsulated in Resolution 63 have reshaped the nature of agriculture and impacted rural communities in Vietnam. To do so, it draws on survey data collected from rural households in Bạc Liêu province, in the Mekong River Delta, to argue that the implementation of Resolution 63 has resulted not just in increased rice production, but also in an erosion of living standards among small farmers, a growing exodus from agriculture and into precarious forms of wage labor, and the concentration of agricultural land in the hands of a small number of large-scale commercial farmers.

\section{Defining the Crisis and Framing the Response: "National Food Security" in a Vietnamese Context}

Resolution (Nghi quyết) No. 63/NQ-CP on Ensuring National Food Security (Đảm Bảo an Ninh Luơng Thực Quốc Gia) was issued by the Prime Minister of Vietnam, Nguyễn Tấn Dũng, on December 23, 2009. The resolution consists of five sections: a preamble which lays out the successes that Vietnam has achieved to date in terms of food security, but also acknowledges the "limitations and shortcomings" which remain to be resolved; a section setting forth basic premises or "viewpoints" (quan diềm) on Vietnam's food security, which affirms that "food security must be part of a general socio-economic development strategy" characterized by industrialization and modernization of the agricultural sector, and that rice and rice production are central to that strategy; a section that lays out "objectives" (muc tiêu) to be achieved by the year 2020, including specific targets for the rate of growth in agricultural output, the area of 
land under rice cultivation, malnutrition rates, food consumption and caloric intake, and farmers' incomes; a section on "major tasks and solutions" (nhiệm vu, giải pháp chủ yếu), including an overhaul of the landuse planning system and new investments in infrastructure, agronomic research and extension, support for rice farmers and traders, and new guidelines on rice trading and export; and finally, a fifth section which assigns responsibility for realizing this strategy to the relevant authorities, including the Ministry of Agriculture and Rural Development and various provincial governments. While it has been supplemented in the intervening years by various decrees outlining concrete actions to be taken by these authorities, Resolution 63 remains the clearest and mostsuccinct formulation of Vietnam's national food security strategy, and the guiding document around which policy interventions continue to be formulated (Yen et al. 2017). The following section consists of a close analysis of its text, paying particular attention to the way in which "food security" is defined, as well as to exploring the historical and political context through which this conceptualization has taken form.

\section{Food Security as Rice Security}

The concept of "food security" is framed in the text of Resolution 63 not around "food" in an abstract or general sense, but around rice specifically. This is implicit even in the term for "food security" used in the text: an ninh luong thư c, which directly translates to "security" (an ninh) of "staple grains" (luo ng thưc), which in the Vietnamese context strongly implies rice. Resolution 63 not only employs this terminology, but specifically highlights rice as the crop and foodstuff most central to Vietnam's longterm food security. The section laying out the government's "viewpoints" on food security, for example, asserts that the "principal task" facing the country is to "bring into play" the country's advantage in rice production (phát huy lợi thế về cây lúa) while one of the "objectives" listed is the intensification of rice farming in the Mekong and Red River Deltas (Government of Vietnam 2009, pp. 49-50). The section on "major tasks and solutions," meanwhile, calls for the development of "planning zones of food production with great outputs of rice," the "strict protection" of 
rice-growing land, and large investments in irrigation canals, sea dykes, and other forms of infrastructure meant to facilitate and protect intensive rice cultivation, while the guidelines offered on scientific research, extension services, and the food trade similarly focus on rice over other foodstuffs (Government of Vietnam 2009, pp. 50-54).

The centrality of rice to Vietnamese food security policy-and the anxieties provoked among both urban consumers and policymakers during the rice price crisis of 2008-reflects the continued primacy of rice to Vietnamese diets and to culturally shaped conceptions of what "food" is and what kinds of food are essential to a well-balanced diet. ${ }^{2}$ Even today, as Vietnam has become more affluent and as diets have shifted accordingly, the average Vietnamese person consumes most of her calories in the form of rice; on average, this translates to 1400 calories per day, equivalent to approximately $170 \mathrm{~kg}$ of rice per capita per year (Hai 2012, p. 3; Tsukada 2011, p. 59). The importance of rice to the Vietnamese diet is especially acute when it comes to the rural poor and urban working class, who are most dependent on this relatively cheap staple (Coxhead et al. 2012), and for whom rice represents a major expenditure, making them extremely sensitive to fluctuations in its price (Ha et al. 2015).

Rice is not just central to Vietnamese diets, but to Vietnamese cultural practices as well. In the Vietnamese language, the word $c$ o $m$, which literally translates as "cooked rice," is used as general term for food. For example, a speaker of Vietnamese would not say whether she has "eaten yet," but whether she "has eaten rice yet" (ăn cơm chua) (Hendry 2009, p. 185). In a country where the daily meals are referred to as cóm sáng, co'm trua, and cơ $m$ tối (literally, "morning rice," "noon rice," and "evening rice"), the Vietnamese conception of a filling and nutritious meal thus hinges upon the presence of rice, without which one might not feel sated. Despite the degree to which baguettes and other foreign foods have been assimilated into Vietnamese culinary culture "a square meal for most, if not all, Vietnamese people" is, as cultural historian Vu Hong Lien notes, "still a meal with rice" (Vu 2016, p. 8). For these reasons, Vietnamese consumers are, as was amply demonstrated in the spring of 2008, extremely sensitive to shortages and price volatility in the rice market, both due to reliance on the grain as a staple and to cultural perceptions around its centrality and irreplaceability. 


\section{Food Security as Food Output and Abundance}

Food security is defined in the resolution not around access or distribution, but around the supply and output of rice. Resolution 63 takes as its central aim that "adequate food supply sources" be achieved and maintained in order to "put an end to food shortage and hunger" (Government of Vietnam 2009, p. 50). In doing so, the Vietnamese government fixates on what food security scholar Per Pinstrup-Andersen calls the "supply side of the equation," while ignoring the fact that mere "availability does not ensure access" (Pinstrup-Andersen 2009, p. 5). This focus on food supply and availability goes against the tendency — at least in academic and global policy circles - to focus on issues of food access and distribution, rather than output figures alone. ${ }^{3}$

This focus on output over access, however, does have some basis in the experiences of post-war Vietnam, in which the intensity of hunger and privation has closely tracked fluctuations in overall food supply. In the decade following reunification in 1975, for example, food shortages were endemic, due to the stagnation of rice production, particularly in the Mekong Delta, in the face of attempts at collectivization by the new socialist authorities (Long 1993). These shortages were greatly alleviated by the Đổi Mới economic reforms of the late 1980s, which reintroduced markets for agricultural commodities and re-privatized land and other factors of agricultural production such as irrigation infrastructure, leading to an explosion of rice production; whereas Vietnam produced fewer than 20 million tonnes of paddy (unprocessed rice) in 1991, that number had increased by more than 50 percent, to over 30 million tonnes, by the end of the decade (Food and Agriculture Organization 2017; see Fig. 8.1). With the explosive growth of Vietnam's agricultural output and the general increase in living standards, the incidence of hunger fell drastically. In 1991, 46 percent of the population was undernourished, but by 2005, that figure had decline to less than 20 percent (Food and Agriculture Organization 2017).

More than a decade of rapid growth in rice output has, however, not completely relegated concerns about food security to the ash heap of history, and in the wake of the rice price crisis, they soon re-emerged, driven 


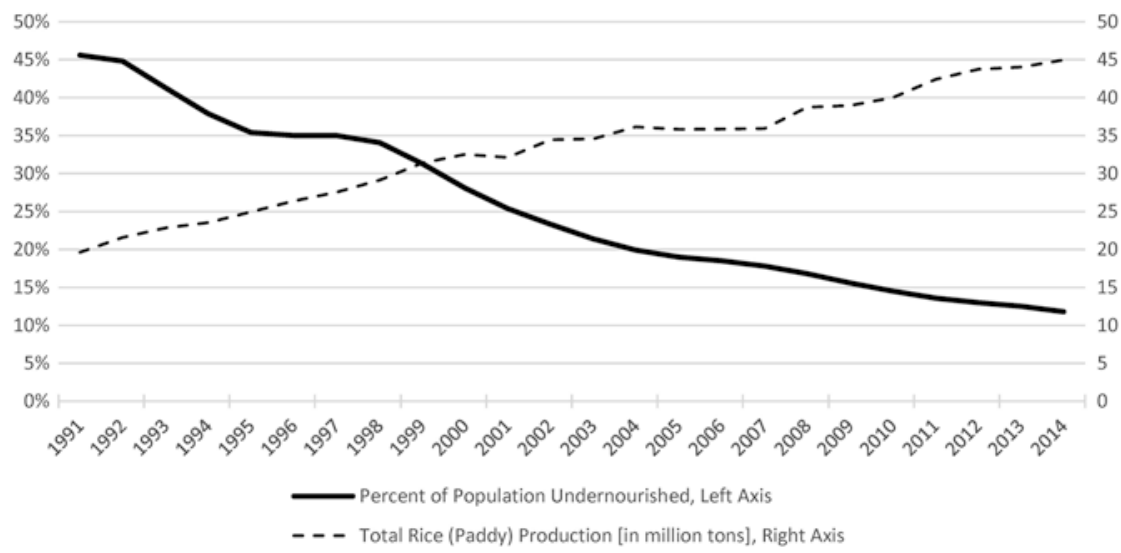

Fig. 8.1 Rice production and undernourishment in Vietnam, 1991-2014. (Source: Food and Agriculture Organization (2017))

by fears that Vietnam's rice output had begun to level off. After rising steadily over the 1990s, paddy production stagnated over the first years of the new millennium, falling off from a high of 36 million tonnes in 2004 and remaining below that peak in the three years leading up to the rice crisis. While such a level of output remained sufficient to meet domestic rice consumption needs, this arrested growth is framed as a major threat to Vietnam's continued food security in Resolution 63. In response, the resolution calls attention to three trends that had contributed to the stagnation of rice output, framing the reversal of these trends as essential to Vietnam's long-term food security.

The first of these trends is the decline in area under rice production. According to a report by the Ministry of Planning and Investment, published at the height of the rice crisis, almost 500,000 hectares of agricultural land were converted to other uses between 2000 and 2008, representing a loss of more than 5 percent of the country's base of agricultural land (Central Institute for Economic Management 2008, p. 20). This rapid loss of agricultural land raised alarm at the highest echelons of the Vietnamese political establishment; in an interview with the newspaper Sài Gòn Giải Phóng in December of 2008, the Minister of Agriculture, Cao Đức Phát, remarked "that the reclamation of agricultural land and 
its conversion to other uses is one of the most important threats to food security" in Vietnam (Nam 2008). Based on projections from Vietnam's Ministry of Agriculture and Rural Development, this trend was expected to continue further, with the total area of rice-growing land continuing on a steady decline from 4.3 million hectares in 2000 to 4 million in 2008 to an anticipated total of 3.6 million in 2020 (Hai 2012). Resolution 63 directly addresses this trend, and declares that 3.8 million hectares should be kept in rice production as a permanent "fund" (quy) of ricegrowing land, to be "kept and strictly protected" by the government, at both the national and local levels (Government of Vietnam 2009, p. 51).

The second threat to rice output that is targeted in the resolution is the stagnation of rice yields in Vietnam. After rising steadily, they too began to level off in the years before the rice crisis (Yu et al. 2010), compounding the effect posed by the dwindling base of rice-growing land. To achieve such yield gains, the Resolution outlines two major policy thrusts: the first being new investment in development and dissemination of new, higher-yielding seed varieties (including genetically modified organisms), and the second the promotion of mechanization, especially of the rice harvest (Government of Vietnam 2009, p. 52). At present, the resolution states, the continued reliance on manual labor allows for significant losses in the harvesting process; it thus sets as a target for 2020 the use of mechanical combines on at least 50 percent of the harvested area, setting the bar significantly higher, at 80 percent, for the Mekong Delta (Government of Vietnam 2009, p. 52).

The third threat to rice output identified in the resolution is potentially the most severe: that of climate change and sea-level rise, which stand to impact food security by degrading agricultural capacity in key rice-growing regions, particularly the Mekong Delta (Government of Vietnam 2009, p. 52). As the seas rise, the tides push salt water up the mouth of the Mekong and into the canals that crosshatch the delta, making the cultivation of rice increasingly difficult, especially during the dry season, when this phenomenon, known as saline intrusion, is most severe. At present, approximately 1.8 million hectares in the Mekong Delta, or about 45 percent of the region's total land area, are affected by saline intrusion (Smajgl et al. 2015, p. 167). By 2050, that figure is projected to increase to 2.1 million, and nearly 300,000 hectares of rice-growing land 
are expected to become uncultivable due to saline intrusion (Yu et al. 2010; Mekong River Commission 2011, p. 175). According to estimates, the adverse impacts of climate change will reduce rice output in the Mekong Delta by 2.7 million tonnes by 2050, representing a 13 percent decrease from 2007 levels (Yu et al. 2010, p. 8). To combat this threat, Resolution 63 calls for broad investment in the construction and improvement of infrastructure systems designed to counteract the threat of sealevel rise and its impact on national food security. These include dikes and other measures to physically seal off vulnerable areas, such as the Mekong Delta, from the rising tides and thus to "protect production and the assets of the state and the people" from the impact of sea-level rise, as well as irrigation canals to ensure the year-round availability of fresh water in "concentrated food production regions" (Government of Vietnam 2009, p. 51).

\section{"National" Food Security as Self-Sufficiency in Rice}

Food security is conceptualized in Resolution 63 as "national food security" (an ninh luóng thực quốc gia), a framing which calls further attention away from issues of access and distribution to the overall balance of food supply and demand at the level of the territorially bounded nation-state. Seen from this perspective, the decline in harvested area and the stagnation of rice yields are problematic because Vietnam's population has continued to grow, threatening the country's continued capacity to meet its own consumption needs without resorting to rice imports. Thus, the resolution takes as its general objective that the growth in rice output overtake the rate of population growth by 2020 (Government of Vietnam 2009, p. 50), reflecting the evident concern of policymakers over the country's ability to feed a population that is expected to grow to 100 million in 2020, and potentially reach 130 million by 2030 , up from just 50 million at the country's reunification in 1975 (McPherson 2012, p. 139). This projection informs the minimum target of 3.8 million hectares of rice-growing land set out in the resolution, which should, if intensively cultivated, provide sufficient rice output to feed Vietnam's projected future population.

This embrace of self-sufficiency goes against several decades of policy orthodoxy by policymakers and economists at multilateral development 
institutions, such as the World Bank and the Food and Agricultural Organization (FAO), which have encouraged countries in the Global South to shift production from staple grains to high-value cash crops, and then use the proceeds from exports to finance food imports. As the chairman of Cargill, one of the world's largest food traders, remarked in 1993, rather than "develop the capacity to grow food for local consumption," countries in the Global South should simply "produce what they produce best - and trade" (Kneen 2002, p. 10). Through structural adjustment agreements and the strictures of free trade agreements like the General Agreement on Tariffs and Trade (GATT), these institutions served to re-orient agriculture in the Global South from self-provisioning and national food security to an "export industry producing 'nontraditional exports' for sale to the developing world" (McMichael and Schneider 2011, p. 122); examples of such non-traditional exports include fresh fruits and vegetables, as well as meat and farmed seafood.

The cost of such specialization in non-traditional exports is, however, an increased reliance on imported staples, and with it an intensified exposure to the vicissitudes of global food markets. While all staples have demonstrated some price volatility in recent years, the global rice market is "notoriously unstable," in the words of economist Peter Timmer, due to the relatively small volume of rice that is traded internationally in proportion to global demand (Timmer 2015, p. 49). This instability was on abundant display during the price crisis of 2007-2008, when the global rice price increased by more than 300 percent in a matter of months. The renewed push for self-sufficiency encapsulated in Resolution 63 reflects, therefore, not just concerns over falling output, but rising anxieties on the part of Vietnamese policymakers over Vietnam's integration into global food markets, and increasing skepticism that such markets could be relied upon as a source of rice imports in times of global economic crisis. A food security strategy document drafted by the Center Institute for Economic Management (part of the Ministry of Planning and Investment) at the height of the crisis in 2008 pointed, for example, to the "global turmoil" and the "chaotic situation of the food market that is now playing out in many countries," as a reason for which the Vietnamese state and communist party must re-affirm their commitment to "ensuring food security for the future" so as not to become reliant on such 
markets for supplies of vital staples such as rice (Central Institute for Economic Management 2008, p. 16).

Vietnam was not alone in reaffirming its commitment to food selfsufficiency and limiting its exposure to global market forces in the aftermath of the crisis. Indeed, as Timmer observes, the crisis drove "policymakers in rice-consuming countries," especially those in Southeast Asia, "to insulate their domestic rice economies from the world market" (Timmer 2015, p. 49), as by promoting the settlement of new agricultural land in Malaysia and building new irrigation infrastructure in the Philippines (McCulloch and Timmer 2008; Trethewie 2012; Alavi et al. 2012, pp. 79-80). This trend was so pervasive that a 2012 World Bank report on the crisis and policy response in Southeast Asia attributed these efforts to a "perception, deeply embedded in the Asian culture and political psyche, that food security is best defined as self-sufficiency, especially in rice" (Alavi et al. 2012, p. 34).

\section{Food Security as Political Imperative}

Finally, Resolution 63 affirms the leading role and responsibility of the Vietnamese state in ensuring "national food security," as defined within the parameters outlined above. By nature of its relatively dense population and scarcity of arable land, and of its exposure to environmental hazards such as drought, floods, and typhoons, Vietnam has always been vulnerable to food shortages. Throughout its history, Vietnam has also been heavily influenced by Confucian political thought, which places a strong emphasis on the prevention of famine as central to the responsibilities of the sovereign and necessary to the maintenance of a wellordered society. Confucius is recorded, for example, as listing the key "requisites of government" as "sufficiency of food, sufficiency of military equipment, and the confidence of the people in their ruler" (Confucius 1971 , p. 254). If, by contrast, the government was unable to ensure adequate supplies of food, it was taken as a sign that the king had lost the "mandate of heaven," and thus his legitimacy (Woodside 1989). Indeed, famine was a potent driver of unrest and rebellion throughout Vietnam's pre-colonial history, and the maximization of rice production remained a 
consistent concern of its kings (see Peters, this volume). In 1460, for example, when Lê Thánh Tông took the throne, he immediately issued an edict "exhorting rural people to grow as much rice as possible," and "repeatedly reminded" local officials "to check that all available land was in production" (Taylor 2013, p. 218). Centuries later, the kings of the Nguyễn dynasty pursued the settlement and clearance of the Mekong Delta as a means of relieving demographic pressures and increasing the food supply by bringing new lands under cultivation (Nguyen-Marshall 2005, pp. 22-23).

The capacity for food shortages to spark social unrest and catalyze political change has, if anything, intensified in recent decades. In the waning days of World War II, the disruption of south-north shipping by Allied bombing and the hoarding of rice by French and Japanese authorities touched off a horrific famine that killed upwards of a million in northern Vietnam, setting the stage for Ho Chi Minh's abortive seizure of power and declaration of Vietnamese independence in September of 1945 (Gunn 2014). In light of the evident ability of food shortages to spark social unrest and political upheaval, the Vietnamese Communist Party has, since coming to power in the 1950s, focused on "self-reliance" in food as one of its primary concerns, and made great "efforts to industrialize the agricultural sector as a way to achieving food self-sufficiency" (Tran Thi Thu 2011, p. 71). Even these efforts, however, were not enough to ward off endemic rice shortages in the 1980s. These shortages eventually culminated in the storming of warehouses and granaries by hungry peasants in the Red River Delta in 1986, an event which contributed to the promulgation of the Đổi Mói reforms in that same year (Kerkvliet 2005, p. 208).

The political potency of hunger and food insecurity is, of course, not unique to Vietnam, a fact demonstrated in abundance at the peak of the food price crisis in 2008. Across the Global South, high prices and scarce supplies touched off food riots and social unrest, culminating in the uprisings of the Arab Spring. That the uprisings in Egypt and elsewhere, as with the 2007 "Saffron Revolution" in Myanmar, were triggered in part by rising food prices, could not have been lost on Vietnamese policymakers (Coe 2014; Kingston 2008). As a recent review of Vietnam's food security policies, composed by senior staffers at the Ministry of Planning and Investment, put it, "solving the problem of food insecurity" 
comprises the "fundamental base for Vietnam's social and political stability" (Yen et al. 2017, p. 44). To this end, the re-affirmation of selfsufficiency in rice as a strategic goal in the aftermath of the 2008 price crisis reflects the view, long held by the country's leadership, that the supply and price of rice are "far too important" to Vietnam's social and political stability "to be left to the whims of an unstable world market" (Timmer 1993, p. 200), and that instead the country must continue to rely on domestic production to satisfy demand for this crucial staple (see Zhang, this volume).

\section{From Food Crisis to Agrarian Crisis: Self- Sufficiency at What Cost?}

The way in which food security is defined by the Vietnamese government in Resolution 63-in terms of rice output and the balance between consumption and production at the national level—directly shaped the policies pursued in the aftermath of the rice price crisis. This section first examines three of these policy interventions, including the embrace of land-use planning as a means of ensuring Vietnam's long-term selfsufficiency in rice production, renewed investment in infrastructure projects meant to stave off the impacts of climate change and to facilitate the intensification of rice production, and the use of subsidies and other supports to encourage the modernization and mechanization of rice production. The remainder of the section then looks at the ways in which these concrete policy interventions have shaped social conditions in ricegrowing areas, drawing on survey data from Bạc Liêu province in the Mekong Delta.

\section{Policy Initiatives: From Conceptualization to Implementation}

The first policy intervention outlined in Resolution 63 is the endorsement of land-use planning as a means to achieve food security and selfsufficiency, an effort which builds on the socialist-era legacy of centralized 
natural resource management. In the language of the resolution, "national food production must be based on the utilization of the advantages of each region, the efficient use of land and water resources, with priority given to planning zones of food production with large output in rice ... in order to achieve national food security targets" (Government of Vietnam 2009, p. 50). Of such zones, the one to which the resolution attaches the greatest importance is the Mekong Delta, the nation's largest rice-producing area.

As McPherson notes, the principal means by which the Vietnamese government aims to achieve its vision of food security and goal of rice self-sufficiency is through "explicit controls over rice land" (McPherson 2012, p. 138). Thus, the vision of planning endorsed in Resolution 63 is primarily a negative one, aimed at halting the further conversion of ricegrowing land to other uses and thus ensuring that the area under rice cultivation does not fall below the 3.8-million-hectare minimum set forth in the resolution. A subsequent policy document, Decree (Nghi dinh) No. 42/2012/ND-CP on the Management and Use of RiceGrowing Land (Quản lý, Sử dung Đất Trồng Lúa), elaborates on the restrictions laid out in Resolution 63, forbidding the transfer of land out of rice production except "for purposes of national defense and security," or in other cases of "national and public interest" (Government of Vietnam 2012, p. 2).

While vague on many points of implementation, Resolution 63 does set out, in detail, a new set of procedures by which local and provincial governments must realize the rice cultivation targets of the central government through the planning apparatus: first, local authorities must draft detailed land-use plans, which set aside specific areas for rice, as well as the cultivation of perennial crops, forestry, aquaculture, and industrial and residential use; then, these detailed plans must be submitted to the Prime Minister for approval; once the plans are finalized, any additional changes to the plan that involve the conversion of rice-growing land to other uses must be resubmitted to the Prime Minister's office for approval, essentially centralizing control of even the most minute details of agricultural land-use planning at the uppermost levels of the government. The Resolution, however, assigns the primary responsibility for "strictly managing the fund of agricultural production land, especially planned rice 
land" to the provincial authorities, who are to punish any violators of the land-use plan through fines and other means. Although the enforcement of such restrictions may vary, it has been noted elsewhere that, on the whole, "land use planning is most strictly enforced in rice cultivation" (Giesecke et al. 2013, p. 1202).

The second intervention outlined in Resolution 63 is a call for greater investment in infrastructure, to both support the intensification of existing rice agriculture and to offset the potential damage posed by climate change. The resolution includes specific calls for the development of irrigation infrastructure to serve at least 3.2 million hectares of rice-growing land, as well as for "investment in building new dike systems" as a means of "coping with sea level rise" (Government of Vietnam 2009, p. 51). The reliance on infrastructural solutions to Vietnam's long-term food security challenges, as outlined in Resolution 63, is reflected in a number of largescale water control projects launched in the aftermath of the food price crisis. In 2012, the Prime Minister's office issued a new water resources development plan for the Mekong Delta region, which committed VND 107,700 billion (equivalent to over USD 5 billion) to the construction of sea dykes, flood control systems, and irrigation canals intended to mitigate the impact of climate change and to maintain the region's high level of agricultural output (Benedikter 2014, pp. 115-116).

The third intervention outlined in the resolution is a new set of measures aimed at supporting the modernization and mechanization of agriculture through enhanced subsidies and supports. In broad terms, this allocation of resources illustrates the commitment of the Vietnamese state to maximizing rice production and achieving its stated goal of rice self-sufficiency not solely through the use of coercive land-use policy, but also through positive inducements designed to make rice production more rewarding for individual producers. These measures include a subsidy of VND 500,000 to 1 million (equivalent to approximately USD 25-50) per hectare per year for land under rice production, the exemption of agricultural land from taxation, a reduction on tariffs for imported machinery, pesticides, and fertilizers, and the indefinite suspension of irrigation charges (Hai 2012; Yen et al. 2017; Thang and Linh 2015). Additionally, the Vietnamese government has subsidized loans taken out by farmers for the purchase of agricultural inputs (Yen et al. 2017, p. 55), 
supplied support to rice farmers hit by natural disasters and disease outbreaks, and provided subsidies for expenses involved in "reclaiming" or clearing land for rice cultivation (Thang and Linh 2015).

\section{From Intervention to Impact: Food Security Policy and Agrarian Transition in Bạc Liêu}

This section draws on key concepts from the field of agrarian studies to argue that the implementation of the food security strategy outlined in Resolution 63 has intensified an ongoing process of "agrarian transition" in the case study area (Byres 1977). As defined by T. J. Byres, an agrarian transition is a process by which "capitalism becomes the dominant mode of production in agriculture" (Byres 1977, 258). While the form taken by capitalist agriculture varies from context to context, its distinguishing factor is the "central importance of productive capital" in farming and the reinvestment of profits in "an endless cycle of accumulation" whereby such capital, such as land and machinery, is continuously acquired and productive capacity expanded (Bernstein 2010). In the Mekong Delta, this transition has been defined by the shift toward more intensive and mechanized rice production on relatively large farms. With this transition have come both changes in the nature of rice production itself and in the broader social relations around agriculture, leading to increasing social polarization and bringing adverse consequences to the smallholder farmers who once comprised the social base of rice production in the study site. To explore these changes, this section focuses on a single village in Bạc Liêu province, in the Mekong Delta, drawing on household surveys from the periods before and after the rice crisis and the issuance of Resolution 63.

Bạc Liêu province (see Fig. 8.2) is an ideal location in which to examine the impacts of the food security strategy laid out in Resolution 63, since it is heavily impacted by two trends identified in the resolution as major threats to Vietnam's long-term food security: the conversion of rice-growing land to other uses and the adverse impact of saline intrusion and sea-level rise on intensive rice cultivation. Between 1996 and 2006, the production of farmed salt-water shrimp, mainly tiger prawn (Penaeus 


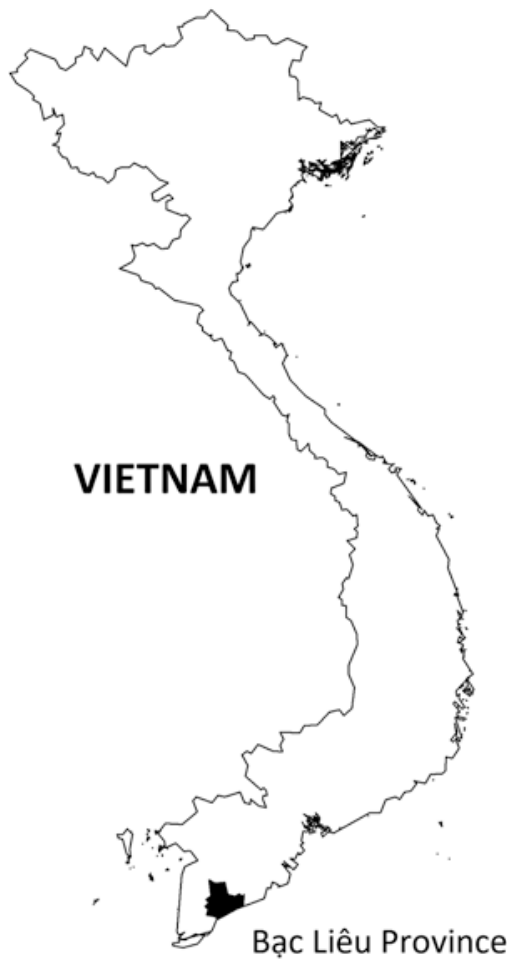

Fig. 8.2 Location of Bạc Liêu province in Vietnam. (Source: Generated by author using shapefile from the GADM Database of Global Administrative Areas, Version 2.8 (http://www.gadm.org). Used with permission by Robert J. Hijmans, database developer)

monodon) in Bạc Liêu increased more than tenfold, from under 6000 tonnes per year to more than 60,000. Over the same period, the surface area used for aquaculture ponds nearly tripled, from 42,600 hectares to 120,200 (see Fig. 8.3). As shrimp production exploded, rice production in the province declined, from a high of 893,500 tonnes of paddy in 2000 to an average of just 655,000 over the five-year period between 2004 and 2007, a decline mirrored by a drop in the area of rice harvested per year (see Fig. 8.4). By virtue of its proximity to the coast and its location in the Cà Mau peninsula, Bạc Liêu is heavily affected by saline intrusion, as tidal forces drive salt water inland via rivers and irrigation canals 


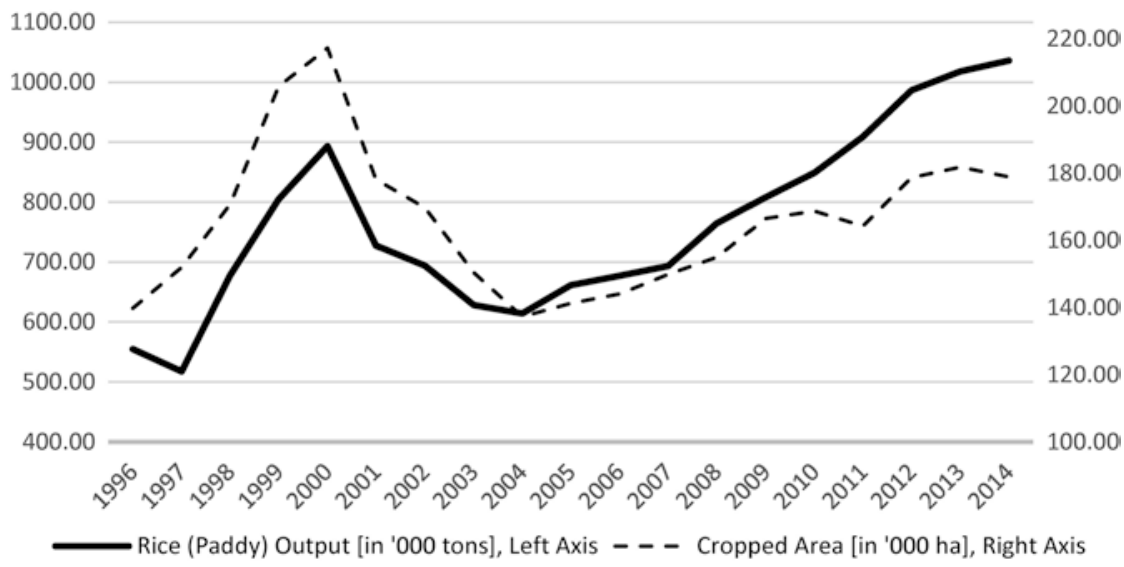

Fig. 8.3 Rice output and cropped area, Bạc Liêu province, 1996-2014. (Source: http://fsiu.mard.gov.vn/data/trongtrot.htm)

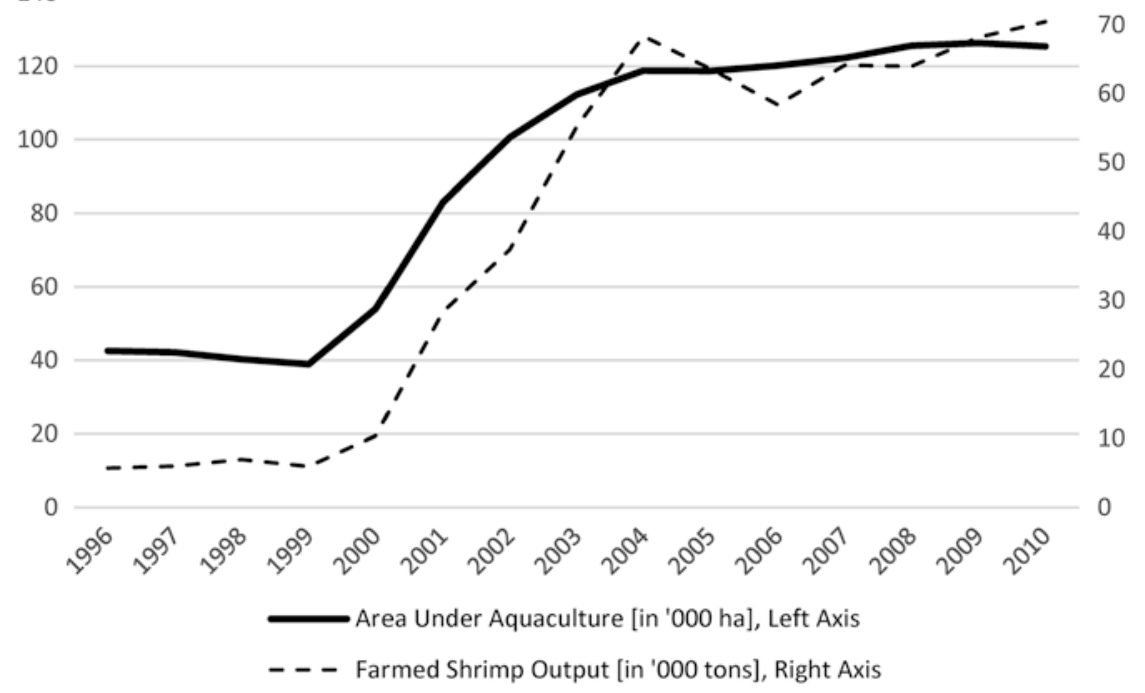

Fig. 8.4 Farmed shrimp production and area under aquaculture, Bạc Liêu province, 1996-2010. (Source: http://www.gso.gov.vn/default_en.aspx?tabid=469) 
(Kotera et al. 2008). As the seas rise, this phenomenon will only intensify, putting the future of rice cultivation in Bạc Liêu at risk, unless significant investments are made in protective infrastructure (Tuan and Chinvanno 2011; Smajgl et al. 2015).

To arrest the decline in rice production and rice area in Bạc Liêu, Vietnamese authorities have relied on land-use planning and on the construction of physical infrastructure meant to blunt the adverse impact of global climate change. In 2010, 77,610 hectares, or about one-third of the province's total area, was under intensive rice cultivation; according to the land-use plan developed by the province and approved by the national government in 2012, however, this area is to be expanded to 83,000 hectares by the year 2020 (Government of Vietnam 2013). To make the expansion and intensification of rice agriculture possible, the national government has since 2009 invested VND 691 billion (or approximately USD 35 million) in a system of 66 sluice gates, designed to seal off irrigation canals and block the inflow of salt water into the rice-growing areas of Bạc Liêu (Ministry of Agriculture and Rural Development 2017). The active measures taken by the Vietnamese government in recent years to protect and intensify rice production in Bạc Liêu have borne significant fruit, as evidenced by the dramatic uptick in both overall rice output and total area cropped since 2010 (see Figs. 8.4 and 8.5). In 2013, for example, paddy production in Bạc Liêu surpassed, for the first time, 1 million tonnes per year, up from a low of 614,000 tonnes in 2004.

Against this backdrop of increased rice production-and the seeming success of efforts to ensure Vietnam's food security and self-sufficiency by boosting rice output in places such as Bac Liêu - the remainder of this section seeks to assess the impact of such land-use planning and infrastructural measures on the social and class relations around agriculture, using a village, identified here by the pseudonym "Hòa Bình" (after the district in which it is located), as a case study (see Fig. 8.5). This case study draws on socio-economic survey data from 2001, collected by Tran Thi Ut and researchers from the International Rice Research Institute (Tran Thi Ut 2004), as well as a follow-up survey conducted by the author and research assistants from Cần Thơ University in 2014. In each iteration, every household in Hòa Bình village was surveyed, for a total of 162 


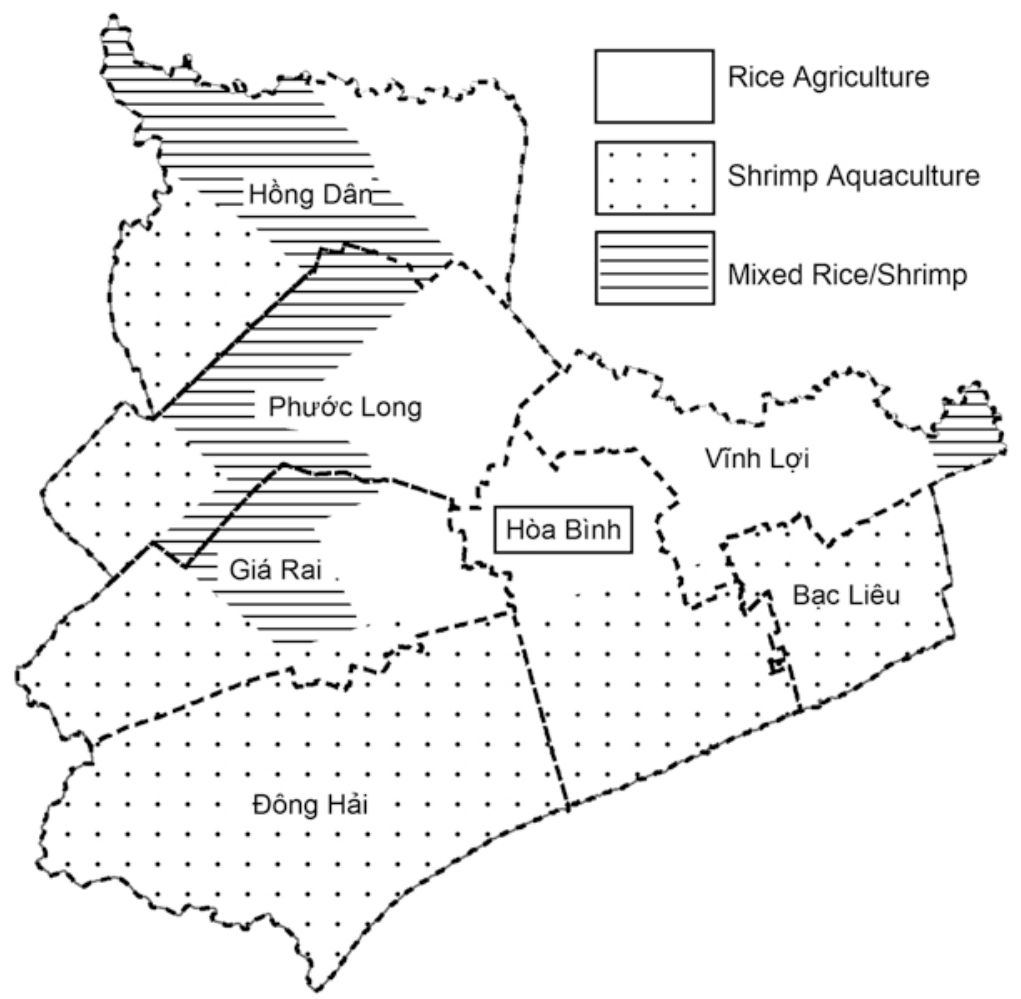

Fig. 8.5 Land-use map of Bạc Liêu province with district names and case study site (Hòa Bình). (Source: Generated by author using shapefile from the GADM Database of Global Administrative Areas, Version 2.8 (http://www.gadm.org). Used with permission by Robert J. Hijmans, database developer)

households in 2001 and 223 in 2014, allowing for a comparison of socioeconomic conditions and agrarian livelihoods in the period before the food crisis in 2007-2008 and that which followed the issuance of Resolution 63 in 2009.

The first and most glaring result which may be gleaned from these data is a dramatic upsurge in rice production, surpassing even the significant gains made at the provincial level. In 2001, for example, households in the village cultivated a total of 219.5 hectares of rice land, almost all of which was used to produce two crops per year, and harvested a total of 1880 tonnes of rice. By 2014, however, the area under rice cultivation 
had increased from 219.5 hectares to 322.5 hectares, as new irrigation and salinity-control works made more of the land in the village suitable for rice agriculture, and as the stringent enforcement of the land-use plan constricted alternative cropping practices, such as aquaculture or the cultivation of fruit and vegetable gardens. By the time of the re-survey in 2014 , all of the rice-growing households in the village (both those with large and small holdings) had switched from growing two crops of rice to three per year, in response to changes to the land-use plan and exhortations by local authorities, as well as to the newly built sluice gates, which afforded protection from saline intrusion and thus made the cultivation of an additional dry-season crop feasible.

As a result, the total harvest in Hòa Bình village increased more than threefold during the period between the two surveys, reaching a total of 6006.5 tonnes in 2015. This dramatic increase in agricultural output, however, belies a significant reduction in the social basis of rice production, and in particular the relative decline of farming as a primary means of livelihood and of smallholder owner-operators as a class. This can be seen first by examining the rate of participation in rice agriculture. In 2001, 91 percent of households in the village (147 of 162) were directly involved in rice production. By 2014, that share had dropped to 81 percent (or 181 of 223 households), but this fails to capture the full extent of the decline in the primacy of rice farming as a livelihood.

A closer examination of the data on household income sources illustrates, in more striking detail, the shift away from smallholder rice farming. In 2001, more than three quarters of the households in the village (122 of 162) were primarily self-employed agriculturalists: that is, they derived more than half their total household income from agriculture and less than half of their income from wages, both in the agricultural sector and beyond (see Fig. 8.6). By 2014, however, fewer than half of all households in the village (or 109 out of 223) were primarily self-employed farmers, while the share of households primarily dependent on nonagricultural wage labor (such as construction or factory work) increased dramatically, from 3.7 percent to 25.6 percent.

This movement out of agriculture is in keeping with a broader trend, observed across the Global South, of "de-agrarianization," whereby rural households derive a decreasing share of their incomes from farming 


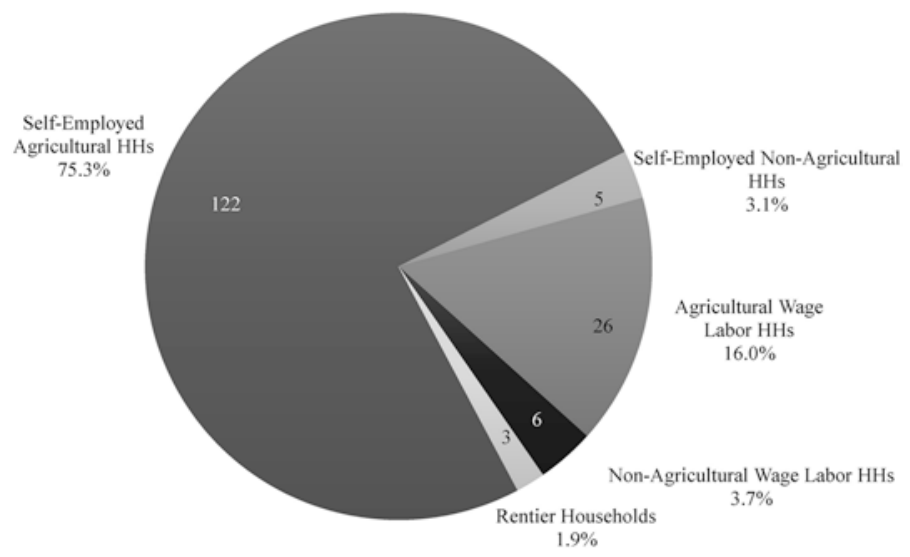

Class Structure in 2001

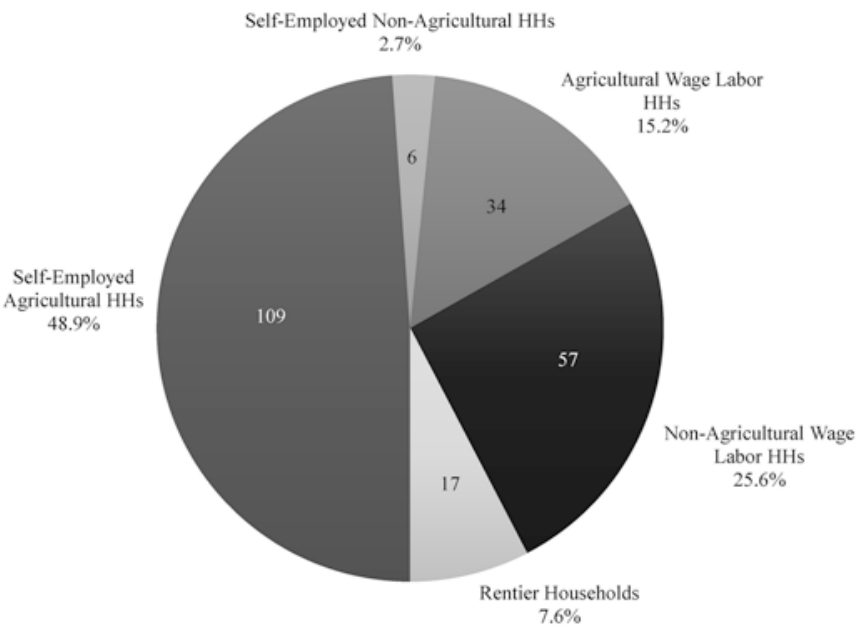

Class Structure in 2014

Self-Employed Agricultural Households

Receive $>50 \%$ of Income from Agri-/Aquaculture \&

Receive $<50 \%$ of Income from Wages

Agricultural Wage Labor Households

Receive $>50 \%$ of Income from Agri-/Aquaculture \&

Receive $>50 \%$ of Income from Wages
Non-Agricultural Wage Labor Households Receive $<50 \%$ of Income from Agri-/Aquaculture \& Receive $>50 \%$ of Income from Wages

Self-Employed Non-Agricultural Households

Receive $<50 \%$ of Income from Agri-/Aquaculture \& Receive $<50 \%$ of Income from Wages

Rentier Households

Receive $>30 \%$ of Income from Renting out Land and Machines

Fig. 8.6 Changing class structure in Hòa Bình village. (Source: 2001 survey data collected by Tran Thi Ut (2004); 2014 data collected by author) 
(Bryceson 1997; Rigg 2006). As the social base of agriculture declines (i.e. as fewer and fewer households are involved in agriculture itself, even as the overall output and cultivated area increase), there occurs a concomitant process, also widely discussed in the field of agrarian studies, of concentration and accumulation, especially of land. Such a phenomenon has been widely observed in Vietnam over the past two decades, and has been especially pronounced in the Mekong Delta (Akram-Lodhi 2005; Prota and Beresford 2012; Gorman 2014).

Hòa Bình village is no exception to this broader trend, as evidenced by an increase in the percentage and number of households without land. In 2001 , only 7 households in the village (or 4.3 percent of the total) were functionally landless, meaning that they had less than 500 square meters of agricultural land. By 2014, that number had grown to 24 (or 11 percent of the total). Alongside this increase in landless households came the growing concentration of land in the hands of larger farmers. In 2001, for example, the top 20 percent of households owned 105 hectares of agricultural land (or 45 percent of the total agricultural land in the village) while in 2014 that figure had increased to 161 hectares (or 50 percent of the total). This increasing concentration of land can be quantified using the Gini coefficient, which assigns a numerical score (ranging from 0 to 1 ) to assess how equally an asset is distributed among a population, with higher scores indicating more inequality. In 2001, the Gini coefficient for agricultural land was 0.408 , but by 2014 , it had increased to 0.487 (see Fig. 8.7).

What we see occurring in Hòa Bình village is thus a reflection of a broader process of "agrarian transition," now underway in the Mekong Delta, whereby large, highly mechanized, and commercially oriented farms displace the previously dominant model of smallholder, or "peasant," agriculture (Byres 1977; De Koninck 2004). The reasons for this transition can be traced to downward pressures on per-hectare profits, as prices for fertilizer, fuel, pesticides, seeds, and other inputs rise while output prices remain stagnant. As a result of this "price squeeze" (or ép giá in Vietnamese), the profit margin for rice agriculture is thin; in Hòa Bình village, a typical farmer can make a profit of roughly VND 40-50 million, or USD 2000-2500, per hectare per year, assuming that he or she grows three crops and does not experience any significant losses 
0.7

0.6

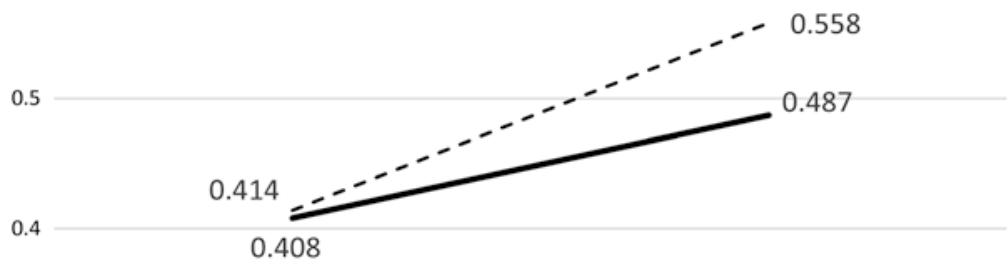

0.3

2001

2014

— Land Gini - - - Income Gini

Fig. 8.7 Gini coefficients for land and income, Hòa Bình Village. (Gini coefficients calculated using ineqdec 0 module in Stata, weighted by household size). (Source: 2001 survey data collected by Tran Thi Ut (2004); 2014 data collected by author)

due to drought, pest outbreaks, storms, or saline intrusion. For small farmers in Hòa Bình, one hectare is a typical holding, and many have even less land; in a country where average gross domestic product (GDP) now exceeds USD 2000 per capita, such a sum is wholly insufficient to meet the needs of an entire family, especially given the rising costs of healthcare and education. ${ }^{4}$

As a result, many households that formerly relied on rice agriculture have become increasingly dependent on other livelihoods and income sources, such as petty trading, casual construction labor in the district town, and, increasingly, remittances from sons and daughters in the industrial zones of Bình Dương and Đồng Nai, located a few hundred kilometers away to the north of Hồ Chí Minh City. While some of these households remain involved in agriculture as a sideline economic activity, many have sold all or part of their farmland to larger operators. As described elsewhere (Gorman 2014), this emerging class of capitalist farmers consists of local villagers who typically received larger plots during the process of post-socialist land privatization in the 1980s and 1990s, and who have been able, through further acquisitions, to amass farms ranging from 5 to 30 hectares. By utilizing economies of scale, these 
farmers are able to reap significant gains through intensive rice production, gains they have re-invested in the acquisition of more land and of machinery such as tractors and combine harvesters.

The end result of such accumulation has not just been increasing inequality in the distribution of land, but of income as well: in 2001, the Gini coefficient for income distribution in Hòa Bình village stood at 0.414 and, by 2014 , it had increased to 0.558 (see Fig. 8.7). What this rising inequality reflects is an increasing gap between the incomes of those households engaged in large-scale rice farming, which frequently exceed VND 50 million (or USD 2500) per capita per year, and those of the former farmers now relegated to non-agricultural wage labor, for which the average income is only VND 13 million (or USD 650) per household member, a figure far below the national average as well as the global poverty threshold of USD 1.90 per person per day used by the World Bank (World Bank 2015).

\section{Conclusion: From Food Crisis to Agrarian Crisis?}

The data from Hòa Bình village illustrate the fundamental paradox of Vietnam's food security strategy: by fostering the development of "modern," mechanized, and large-scale rice production through policy initiatives (such as per-hectare subsidies for rice producers and support for the purchase of mechanical inputs such as combines and tractors) that clearly favor large producers over smallholders, and by promulgating land-use plans and constructing physical structures (such as sluice gates) designed to promote and facilitate intensive rice production, the government of Vietnam has achieved dramatic successes in raising rice output and forestalling the next food crisis. At the same time, however, these interventions have prevented smallholders from engaging in alternative production strategies, such as the cultivation of fruits and vegetables or even the conversion of agricultural land to salt-water ponds for shrimp aquaculture, that might offer higher returns per hectare than rice and thus provide a more viable source of livelihood for those with limited land resources. In this way, the implementation of policies designed to boost rice production 
in the name of national food security have at the same time undermined the position of small farmers who have traditionally comprised the backbone of Vietnamese agriculture.

For those small farmers now being pushed out of rice agriculture at a rapid pace, both in Hòa Bình village and in the Mekong Delta more broadly, there are few attractive economic alternatives. This is especially true for older household members, given the preference for younger workers (and especially women) in the factories of Vietnam's industrial zones. This lack of options is compounded by the disappearance of wage labor opportunities in the agricultural sector itself. In the course of the author's fieldwork, many poorer farmers in the village recounted that they were once able to supplement their incomes by performing seasonal work on the farms of their neighbors, especially at harvest time. With the recent turn to mechanized combine harvesters, however, this source of income has evaporated. As a result, households that once relied primarily on rice agriculture now find themselves dependent on casual manual labor and remittances from family members, both of which provide relatively low, and erratic, income streams compared to farming.

In sum, then, the interventions made by the Vietnamese state in the name of food security, defined for political, historic, and cultural reasons as national self-sufficiency in rice, have contributed to the declining viability of smallholder rice agriculture and to the general air of agrarian crisis in the countryside. Vietnam's unfolding agrarian crisis, though distinct in its particulars, parallels developments elsewhere, such as Latin America and India, where small farmers have found themselves crushed under the weight of rising costs, falling profits, and ballooning debt (De Janvry 1981; Lerche 2011; Shah 2012). In their survey of the current state of agrarian studies and of the key challenges facing agrarian communities in the Global South, Akram-Lodhi and Kay trace the contours of such agrarian crises, wherein "an exclusive emphasis on farming" no longer presents an "adequate survival strategy" for rural households, who instead become dependent on "a plethora of fragmentary and insecure sources" of non-agricultural income, including "the sale of temporary and casualized waged labor," as well as "handicraft manufacture, petty merchant trading, the provision of petty services, and ... remittances arising from migration" (Akram-Lodhi and Kay 2010, p. 179). Though written in broad terms to capture a generalized phenomenon, this summation 
captures perfectly the situation now unfolding in the rice-growing areas of the Mekong Delta. The question, however, remains of whether the Vietnamese state will, almost a decade on the rice price crisis of 2007-2008, continue to prioritize the maximization of rice output as the linchpin of its food security strategy — in the hope of averting the kind of urban unrest that has toppled comparable regimes elsewhere in the world - and by doing so, risk unraveling the social fabric of rural areas in the Mekong Delta and beyond.

\section{Notes}

1. As shown in Fig. 8.1, based on data from the Food and Agriculture Organization, the incidence of malnutrition in Vietnam has plunged since the 1990s, while overall output of food (especially rice) has increased dramatically.

2. A similar point about the cultural centrality of rice in Japan is made by Ohnuki-Tierney (1993).

3. For example, at the 1996 World Food Summit, "food security" was officially defined not as the quantitative abundance of food, but the condition that "exists when all people, at all times, have physical and economic access to sufficient safe and nutritious food that meets their dietary needs and food preferences for an active and healthy life" (Food and Agriculture Organization 1996).

4. According to Vietnam's General Statistics Office, the cost of healthcare and education services rose by 129.28 percent and 131.54 percent, respectively, between 2009 and 2015. In contrast, consumer prices as a whole increased by 59.51 percent (General Statistics Office of Vietnam 2017).

\section{References}

Akram-Lodhi, A. H. (2005) 'Vietnam's Agriculture: Processes of Rich Peasant Accumulation and Mechanisms of Social Differentiation', Journal of Agrarian Change, 5(1), 73-116.

Akram-Lodhi, A. H. and Kay, C. (2010) 'Surveying the agrarian question (part 1): unearthing foundations, exploring diversity', The Journal of Peasant Studies, 37(1), 177-202. 
Alavi, H. R., Htenas, A., Kopicki, R., Shepherd, A. W. and Clarete, R. (eds.) (2012) Trusting trade and the private sector for food security in Southeast Asia (Washington, D.C.: World Bank).

Barrett, C. B. (ed.) (2013) Food security and sociopolitical stability, First edition (Oxford: Oxford University Press).

Benedikter, S. (2014) The Vietnamese hydrocracy and the Mekong Delta: water resources development from state socialism to bureaucratic capitalism (Berlin: Lit Verlag).

Bernstein, H. (2010). Class dynamics of agrarian change (Sterling, Virginia: Kumarian Press).

Brown, L. R. (2012) Full planet, empty plates: the new geopolitics of food scarcity, First Edition (New York: W.W. Norton \& Company).

Bryceson, D. F. (1997) Farewell to farms: de-agrarianisation and employment in Africa (Aldershot: Ashgate).

Byres, T. J. (1977) 'Agrarian transition and the Agrarian question', The Journal of Peasant Studies, 4(3), 258-274.

Central Institute for Economic Management (2008) Đảm bảo An ninh Lương thực trên Thế giới và ở Việt Nam (Ensuring Food Security Globally and in Vietnam), Hanoi: Ministry of Planning and Investment.

Charles, D. (2011). How Fear Drove World Rice Markets Insane. In All Things Considered: National Public Radio.

Clapp, J. and Cohen, M. J. (eds.) (2009) Global Food Crisis: Governance Challenges and Opportunities (Waterloo: Wilfrid Laurier University Press).

Coe, C. A. (2014) 'Minding the Metaphor. Vietnamese State-Run Press Coverage of Social Movements Abroad', Journal of Vietnamese Studies, 9(1), $1-35$.

Confucius (1971) Confucian analects, The great learning, and the doctrine of the mean, (Translated by: Legge, J.) (New York: Dover Publications).

Coxhead, I., Linh, Vu Hoang and Tam, Le Dong (2012) 'Global market shocks and poverty in Vietnam: the case of rice', Agricultural Economics, 43(5), 575-592.

De Janvry, A. (1981) The agrarian question and reformism in Latin America (Baltimore: The Johns Hopkins University Press).

De Koninck, R. (2004) 'The Challenges of the Agrarian Transition in Southeast Asia', Labour Capital and Society, 37(1\&2), 285.

Food and Agriculture Organization (1996) Rome Declaration on World Food Security and World Food Summit Plan of Action. Rome (92-5-503939-3).

Food and Agriculture Organization (2017) FAOSTAT Database. Rome. Available at: http://www.fao.org/faostat/ (Accessed: May 10 2017). 
General Statistics Office of Vietnam (2017) Consumer price index, gold and USD price indexes, December 2015 Available at: https://www.gso.gov.vn/default_ en.aspx?tabid=625\&ItemID=15502 (Accessed: May 10 2017).

Giesecke, J. A., Tran, Nhi Hoang, Corong, E. L. and Jaffee, S. (2013) 'Rice Land Designation Policy in Vietnam and the Implications of Policy Reform for Food Security and Economic Welfare', The Journal of Development Studies, 49(9), 1202-1218.

Gorman, T. (2014) 'Moral Economy and the Upper Peasant: The Dynamics of Land Privatization in the Mekong Delta', Journal of Agrarian Change, 14(4), 501-521.

Government of Vietnam (2009) Resolution No. 63 NQ-CP of December 23, 2009, on National Food Security. Hanoi: Government of Viet Nam. Available at: http://extwprlegs1.fao.org/docs/pdf/vie95278.pdf (Accessed: May 10 2017).

Government of Vietnam (2012) Nghi dịnh số 42/2012/ND-CP về Quản lý, Sử dung Đất Trồng Lúa (Decree No. 42/2012/ND-CP on the Management and Use of Rice-Growing Land). Hanoi: Government of Vietnam. Available at: http:// vnu.edu.vn/upload/vanban/2012/09/28/2012_05_11-42_2012_ND-CP_ Ve-quan-ly-su-dung-dat-tron g-lua.pdf (Accessed: May 10 2017).

Government of Vietnam (2013) Nghi quyết số 51/NQ-CP về việc quy hoạch sử dung dất đến năm 2020 và kế hoạch sử dung đất 5 năm kỳ đà̀u (2011-2015) tinh Bac Liêu (Resolution 51/NQ-CP on Land Use Planning to 2020 and the 2011-2015 Five-year Land Use Plan of Bac Liêu Province). Hanoi: Government of Vietnam.

Gunn, G. C. (2014) Rice wars in colonial Vietnam: the Great Famine and the Viet Minh road to power (Lanham, Maryland: Rowman \& Littlefield).

Ha, Pham Van, Nguyen, Hoa Thi Minh, Kompas, T., Che, Tuong Nhu and Trinh, Bui (2015) 'Rice Production, Trade and the Poor: Regional Effects of Rice Export Policy on Households in Vietnam', Journal of Agricultural Economics, 66(2), 280-307.

Hai, Le Trong (2012) The Rice Situation in Vietnam, Manila: Asian Development Bank.

Hendry, J. B. (2009) Rural Vietnam: the small world of Khanh Hau (New Brunswick: AldineTransaction).

Kerkvliet, B. J. (2005) The power of everyday politics: how Vietnamese peasants transformed national policy (Ithaca, N.Y.: Cornell University Press).

Kingston, J. (2008) 'Burma's Despair', Critical Asian Studies, 40(1), 3-43.

Kneen, B. (2002) Invisible giant: Cargill and its transnational strategies, 2nd ed. (London and Sterling, Va.: Pluto Press). 
Kotera, A., Sakamoto, T., Nguyen, Duy Khang and Yokozawa, M. (2008) 'Regional consequences of seawater intrusion on rice productivity and land use in coastal area of the Mekong River Delta [Viet Nam]', JARQ - Japan Agricultural Research Quarterly, (4), 267-274.

Lerche, J. (2011) 'Agrarian Crisis and Agrarian Questions in India', Journal of Agrarian Change, 11(1), 104-118.

Long, Ngo Vinh (1993) 'Reform and Rural Development: Impact on Class, Sectoral, and Regional Inequalities', in Turley, W.S. \& Selden, M. (eds.) Reinventing Vietnamese socialism: doi moi in comparative perspective (Boulder, Co.: Westview).

McCulloch, N. and Timmer, P. C. (2008) 'Rice Policy in Indonesia', Bulletin of Indonesian Economic Studies, 44(1), 33-44.

McMichael, P. and Schneider, M. (2011) 'Food Security Politics and the Millennium Development Goals', Third World Quarterly, 32(1), 119-139.

McPherson, M. (2012) 'Land Policy in Vietnam: Challenges and Prospects for Constructive Change', Journal of Macromarketing, 32(1), 137.

Mekong River Commission (2011) Assessment of Basin-wide Development Scenarios: Main Report, Basin Development Plan Programme (Vientiane, Lao PDR: Mekong River Commission).

Ministry of Agriculture and Rural Development (2017) Thông tin dự án: Hệ thống phân ranh mặn ngọt tỉnh Bạc Liêu - Sóc Trăng (Project Description: System to Demarcate the Saline-Fresh Boundary in Bac Lieu and Soc Trang Provinces). Hanoi. Available at: http://mic.mard.gov.vn/Project/1051.aspx (Accessed: May 10 2017).

Nam, Thành (2008) Bộ truơng Bộ NN-PTNT Cao Đúc Phát: Thế mạnh của nuớc ta hiện nay vẫn là nông nghiệp (Minister of Agriculture and Rural Development Cao Đúc Phat: The Strength of our Country is Still Agriculture). Sài Gòn Giải Phóng Online. Available at: http://www.sggp.org.vn/bo-truong-bo-nnptnt-cao-duc-phat-the-manh-cua-nuoc-ta-hien-nay-van-la-nongnghiep-276243.html (Accessed: May 10 2017).

Naylor, R. (ed.) (2014) The evolving sphere of food security (Oxford: Oxford University Press).

Ngan, Pham Hoang (2010) 'The Vietnamese rice industry during the global food crisis', in Dawe, D.C. (ed.) The rice crisis: markets, policies and food security (London: Earthscan).

Nguyen-Marshall, Van (2005) 'The Moral Economy of Colonialism: Subsistence and Famine Relief in French Indo-China, 1906-1917', The International History Review, 27(2), 237-258.

Ohnuki-Tierney, E. (1993) Rice as selfJapanese identities through time (Princeton, N.J.: Princeton University Press). 
Patel, R. and McMichael, P. (2014) 'A political economy of the food riot', in Pritchard, D. \& Pakes, F.J. (eds.) Riot, unrest and protest on the global stage (Basingstoke: Palgrave Macmillan).

Pinstrup-Andersen, P. (2009) 'Food security: definition and measurement', Food Security, 1(1), 5-7.

Prota, L. and Beresford, M. (2012) 'Emerging Class Relations in the Mekong River Delta of Vietnam: A Network Analysis', Journal of Agrarian Change, 12(1), 60-80.

Rigg, J. (2006) 'Land, farming, livelihoods, and poverty: Rethinking the links in the Rural South', World Development, 34(1), 180-202.

Shah, E. (2012) "'A life wasted making dust": affective histories of dearth, death, debt and farmers' suicides in India', The Journal of Peasant Studies, 39(5), 1159-1179.

Smajgl, A., Toan, T., Nhan, D., Ward, J., Trung, N., Tri, L., Tri, V. and Vu, P. (2015) 'Responding to rising sea levels in the Mekong Delta', Nature Climate Change, 5(2), 167-174

Taylor, K. W. (2013) A history of the Vietnamese (Cambridge: Cambridge University Press).

Thang, Tran Cong and Linh, Dinh Thi Bao (2015) Rice Policy Review in Vietnam: Food and Fertilizer Technology Center for Asia and Pacific Region. Available at: http://ap.fftc.agnet.org/ap_db.php?id=406.

Timmer, C. P. (1993) 'Food Policy and Economic Reform in Vietnam', in Ljunggren, B. \& Perkins, D.H. (eds.) The Challenge of reform in Indochina (Cambridge, MA: Harvard University Press).

Timmer, C. P. (2015) Food security and scarcity: why ending hunger is so hard, (Translated by, 1st ed. (Philadelphia: University of Pennsylvania Press).

Tran Thi Thu, Trang (2011) 'Food security versus food sovereignty choice of concept, policies, and classes in Vietnam's post-reform economy', Kasarinlan: a Philippine journal of Third World studies, 26(1), 68-88.

Tran Thi Ut (2004) 'Land and Water Resource Management in Coastal Areas: Assessing the Socio-economic Impact of Government Intervention, Bac Lieu Province, Mekong Delta, Vietnam', RCSD Working Paper.

Trethewie, S. (2012) In Search of Food Security: Addressing Opacity and Price Volatility in ASEAN's Rice Sector, Singapore: RSIS Center for NonTraditional Security Studies.

Tsukada, K. (2011) 'Food Security in a Rice-Exporting Country', in Shigetomi, S., Kubo, K. \& Tsukada, K. (eds.) The world food crisis and the strategies of Asian rice exporters (Chiba-shi, Japan: Institute of Developing Economies, IDE-Jetro). 
Tuan, Le Anh and Chinvanno, S. (2011) 'Climate Change in the Mekong River Delta and Key Concerns on Future Climate Threats', in Stewart M., Coclanis P. (eds) Environmental Change and Agricultural Sustainability in the Mekong Delta. Advances in Global Change Research, vol 45 (Dordrecht: Springer), 207-217.

Văn, Hồng (2008) Cơn sốt gạo - cơ hội để nhin lại ("Rice Fever" - An Opportunity to Reflect). Thời báo Kinh tế Sài Gòn (Saigon Economic Times Online) (Accessed: May 10 2017).

$\mathrm{Vu}$, Hong Lien (2016) Rice and baguette: a history of food in Vietnam (London: Reaktion Books).

Woodside, A. (1989) 'History, Structure, and Revolution in Vietnam', International Political Science Review/Revue Internationale de Science Politique, 10(2), 143.

World Bank (2015) FAQs: Global Poverty Line Update. Available at: http://www. worldbank.org/en/topic/poverty/brief/global-poverty-line-faq (Accessed: May 10 2017).

Yen, Vu Hoang, Nhung, Nguyen Hong and Dung, Tran Anh (2017) 'Overview of Vietnam's food security policies', in Petersen, E. (ed.) Vietnam Food Security Policy Review (Canberra: Australian Centre for International Agricultural Research), 44-66.

Yu, Bingxin, Zhu, Tingju, Breisinger, C. and Hai, Nguyen Manh (2010) Impacts of climate change on agriculture and policy options for adaptation: The Case of Vietnam, Washington: International Food Policy Research Institute.

Open Access This chapter is licensed under the terms of the Creative Commons Attribution 4.0 International License (http://creativecommons.org/licenses/ by/4.0/), which permits use, sharing, adaptation, distribution and reproduction in any medium or format, as long as you give appropriate credit to the original author(s) and the source, provide a link to the Creative Commons licence and indicate if changes were made.

The images or other third party material in this chapter are included in the chapter's Creative Commons licence, unless indicated otherwise in a credit line to the material. If material is not included in the chapter's Creative Commons licence and your intended use is not permitted by statutory regulation or exceeds the permitted use, you will need to obtain permission directly from the copyright holder. 